\title{
HEPATOSPLENOMEGALY CAUSED BY AN EXTRACT OF CYANOBACTERIUM MICROCYSTIS AERUGINOSA BLOOM COLLECTED IN THE MANGUABA LAGOON, ALAGOAS -BRAZIL
}

\author{
Zenaldo Porfirio $^{1 *}$; Micheline P. Ribeiro ${ }^{1,2}$; Cicero S. Estevam ${ }^{1,2}$; Ricardo L. S. Houly ${ }^{3}$; Antonio \\ Euzébio G. Sant'Ana ${ }^{4}$
}

${ }^{1}$ Departamento de Patologia, Laboratório de Ciências Microbiológicas do Centro de Ciências Biológicas, ${ }^{2}$ Bolsista de Iniciação Científica do CNPq, ${ }^{3}$ Anatomia Patologia Clínica, Hospital Huniversitário, and ${ }^{4}$ Departamento de Química, Centro de Ciências Exatas e Naturais. Universidade Federal de Alagoas, Maceió, Alagoas, Brasil

Received: October 15, 1998; Returned to authors for corrections: March 25, 1999; Approved: April 20, 1999.

\begin{abstract}
Cyanobacteria (Microcystis aeruginosa), which produce powerful hepatotoxic cyclopeptides, were collected and submitted to the determination of toxicity through intraperitoneal injections made in 30 and 90 days-old Swiss albino mice. The liver and the spleen were histopathologically analyzed and the weight and vital signs development were monitored. Test of toxicity resulted in a $\mathrm{LD}_{50}$ of $154.28 \mathrm{mg} \cdot \mathrm{Kg}^{-1}$. M. aeruginosa represented $95 \%$ of the analyzed biomass. The ratios between liver weight and body weight in the animal inoculated with a single dose were $6.0 \%$ and $7.2 \%$, with multi doses $7.0 \%$ and $7.5 \%$ and in the control animals $4.0 \%$ and $5.0 \%$, for adult and young animals, respectively. There was an accentuated increase in the volume and weight of the spleen, and the animals inoculated with a single dose showed a ratio between spleen weight and body weight of $0.67 \%$ and $0.37 \%$, with multidoses $1.22 \%$ and $1.05 \%$ and the control animals the ratio was $0.12 \%$ and $0.15 \%$, for adult and young animals, respectively. The young animals inoculated with single and multi doses had an increase of $150 \%$ and $407 \%$ in the spleen size while the adults increased, $607 \%$ and $845 \%$, respectively, in relation to the control. The histopathological analysis showed strong differences in the structure of the hepatic parenchyme in control animals and in those exposed to the M. aeruginosa extract. The main alterations were the congestive aspect, including the sinusoid, and intrahepatic haemorrhagia. The histopathological analysis showed considerable increase in the number of multinuclear giant cells in the spleen of the animals intoxicated by M. aeruginosa.
\end{abstract}

Key words: Microcystis aeruginosa, cyanobacteria, hepatomegaly, splenomegaly

\section{INTRODUCTION}

The blooms of toxin-producing cyanobacteria frequently observed in estuary and lagoon environments have been registered in various parts of the world and have caused the intoxication and death of domestic and wild animals $(4,5,12,16,17$, $23,26,27)$.

\footnotetext{
* Corresponding author. Mailing address: Departamento de Patologia, Centro de Ciências Biológicas, Universidade Federal de Alagoas, Praça Afranio Jorge S/N, Prado, CEP 57010-020, Maceió, Alagoas, Brasil. Fax: (+5582) 2212501. E-mail: porfirio@fapcal.br
} 
According to Pearson (18), the toxins produced by cyanobacterium may be accommodated into three categories: neurotoxins, hepatotoxins and lipopolisaccharides. The hepatotoxins, such as the microcystins produced by Microcystis, Oscillatoria, Anabaena and Nostoc, are the most studied and have been involved in the majority of the environmental incidents. They are cyclic peptides formed by seven amino acids. Two positions at the structural chain of these microcystins may be occupied by different amino acids which form a series of distinct molecules and the most common and toxic is the microcystinLR that present in the variable positions the amino acids leucine and arginine $(4,20)$. Aphanizomenon is another species, less cited in the literature, though it may cause numbness in fishes and may be transmitted to man through consumption (3). The predominant species in the plankton of fresh and brackish water belong to the genera Anabaena, Nodularia, Coelosphaerium, Microcystis, Aphanizomenon, Gloeotrichia and Oscillatoria, all involved in incidents connected with poisoning of animals (8).

The presence of cyanobacterial toxins in rivers and water reservoirs, used as drinking water sources, has been of great concern to health investigators and authorities around the world. Recently, in Caruaru/ Brazil, 1996, there was an accident in a hemodialysis center, and the death of 56 patients was attributed to a hepatic intoxication caused by toxins present in the water. The toxic effects and the risks to the population due to the presence of cyanobacteria in water sources are very big and the critical examples are diarrhea, nausea, muscle weakness, cutaneous paleness and liver tumors $(4,6,13)$. Another aggravating point is the persistence of cyanobacterial toxins in water when they are not removed or destroyed by the conventional treatment system exposing the population to the consequences of these toxins $(1,14)$.

In the Estuary-Mundaú/Manguaba Lagoon Complex (CELMM), in Alagoas/Brazil (9 $9^{\circ} 35^{\prime} 00^{\prime \prime}$ $9^{\circ} 45^{\prime} 00^{\prime \prime}$ S. Lat. and $35^{\circ} 42^{\prime} 30^{\prime \prime}-35^{\circ} 57^{\prime} 30^{\prime \prime} \mathrm{W}$. Long.), the blooms of cyanobacterium are popularly known as "verdete" due to their green color on the water surface. The CELMM is the major food and income source for the people living at the lagoon neighborhoods.

In this study, we studied the toxicity to mice of $M$. aeruginosa collected at the estuary of the Manguaba lagoon. $\mathrm{LD}_{50}$ valves were determined and physical and histopathological evaluations of the liver and the spleen of the animals were also done.

\section{MATERIALS AND METHODS}

\section{Sampling}

The samples of cyanobacterium and water were collected at the surface of water sources in the "Camurupim Station" of the Manguaba Lagoon, Maceió-AL, Brazil. A plankton collecting net (mesh $45 \mu \mathrm{m}$ ) was used to determine the concentration of plankton plant species. The water samples were placed in snap cap glass recipients with a capacity of $250 \mathrm{ml}$ and fixed with $4 \%$ formaldehyde. The plankton samples for the bioassay were placed in plastic bottles and taken to the laboratory in a box with ice.

\section{Concentration of the plankton sample}

The plankton plant sample was concentrated through filtration in a plankton net (mesh $45 \mu \mathrm{m})$ at the collecting site and then frozen at $-20^{\circ} \mathrm{C}$. The sample was freeze-dried in the laboratory using a micromodular lyophilizer (Edwards, Crawley, England). Every algae extract was frozen $-20^{\circ} \mathrm{C}$ until assayed.

\section{Identification of plankton plant species}

$0.1 \mathrm{ml}$ of the sample maintained in formaldehyde (4\%) was examined in an optical microscope for the determination of plankton plant species, according to Desikachary (10), Sournia (24), Bourdley (2), Eskinazi-Leça (11), Tregouboff and Rose (25), Silva (22) and Chamixaes (7).

\section{Inoculum preparation and $\mathrm{LD}_{50}$ determination}

The toxicity and $\mathrm{LD}_{50}$ of the sample were determined through intraperitoneal injection of the algae extract in male Swiss albino mice. Increasing concentrations $(77.14 ; 154.28 ; 308.57 ; 462.85$ and $617.14 \mathrm{mg} / \mathrm{Kg}$ of animal weight) of the algae extract were prepared in $0.9 \%$ salt solution and applied in the peritonium $(0.1 \mathrm{ml}$ of sample per $10 \mathrm{~g}$ of body weight). A control, containing only $0.9 \%$ salt solution, was also included. The experiment was carried out in quadruplicates, using mice weighing $35.15 \pm 2.43 \mathrm{~g}$. After applications, animals were observed during a period of 48 hours, kept in an aerated place with food and water. 


\section{Bioassay conducted to develop mice hepato and splenomegaly}

Animals were selected according to their weight. Young and adult animals, respectively 30 and 90 days old, were used.

The animals were inoculated with sublethal doses. Each animal of the groups of young and adult animals received a single application of 38.57 mg. $\mathrm{Kg}^{-1}$ of $M$. aeruginosa. To another group of adult animals, 5 doses of $30.85 \mathrm{mg} . \mathrm{Kg}^{-1}$ of $M$. aeruginosa were applied at every 72 -hours. $\mathrm{LD}_{50}$ was determined as described above.

All experiments were done in quadruplicates using young and adult animals. After 14 days, animals were weighed and anesthetized (see procedures below) for the extraction of liver and spleen. The weight of the liver and spleen was determined.

\section{Biopsy}

At the end of the experiments, the animals were submitted to a biopsy for morphological analysis of their organs and fixed in 10\% formaldehyde for histopathological analysis, according to the following steps:

1. Anesthesy - The animals were placed in closed containers with sulfuric ether wetted cotton. After loosing conscience and living signals, they were taken to the surgery room.

2. Surgical Preparation and Animal Biopsy Nippers, scissors and scalpels were used for the surgical opening of the animals. After being fixed to the surgical table, skin and muscles of the abdominal wall were opened, maintaining the peritoneal integrity in order to evaluate the extension of the organs and the wounds provoked by local infection. Afterwards, the peritoneum was opened for morphological analysis and posterior removal of the liver and spleen.

\section{Statistical Analysis}

The statistical analysis of the experimental data (maximum and minimum, standard deviation e standard error) was done using GraphPad Prism version 1.03 software.

\section{RESULTS}

In the samples of water collected at the Manguaba Lagoon, 95\% of the analyzed biomass was represented by $M$. aeruginosa. The minimum lethal dose which killed more than $50 \%$ of the animals $\left(\mathrm{LD}_{50}\right)$ was 154.28 mg. $\mathrm{Kg}^{-1}$. Figs. 1 and 2 show that there is a visible disproportion of the sizes of liver and spleen in control and in the inoculated animals. Fig. 1 shows animals with the total peritoneum and Fig. 2 shows animals with the peritoneal muscles cut.

As shown in Fig. 3, there was a reduction of $13.14 \%$ to $10.00 \%$ in the weight of young and adult animals, respectively, inoculated with a sublethal dose of $M$. aeruginosa. The inoculated young animals gained the same weight as the control animals (Fig. 3). In the bioassay with adult animals, the loss of weight was not recovered during the experiment, even in animals inoculated with a single dose (Fig. 3).

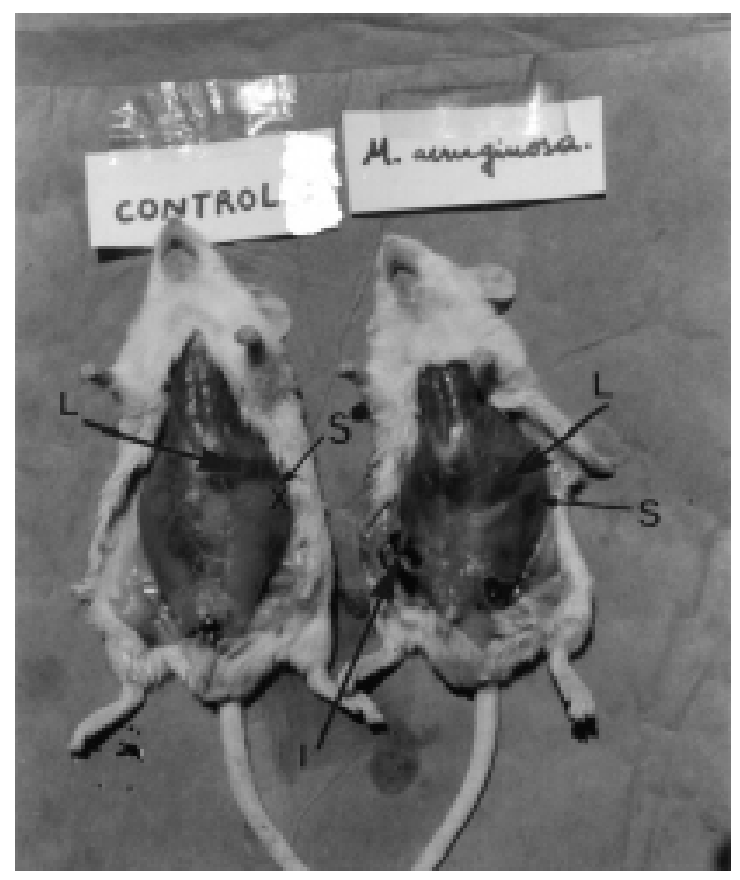

Figure 1. Photography of mice (control and inoculated with sublethal doses of $M$. aeruginosa). Showing an increase of the liver (L) and spleen (S) sizes in the inoculated animal. I is the inoculation point and $\mathrm{X}$ indicates the location of spleen in the non-inoculated animal.

These data are inaccordance with the results indicated in Fig. 4, which shows that the weight of the liver of young animals inoculated with a single dose of $M$. aeruginosa increased between $12 \%$ and $16 \%$, while in the adult animals the increase was between $48 \%$ and $72 \%$, in relation to the control. The weight proportion of the liver in the control animals was around $4 \%$ and $5 \%$, respectively, in young and 


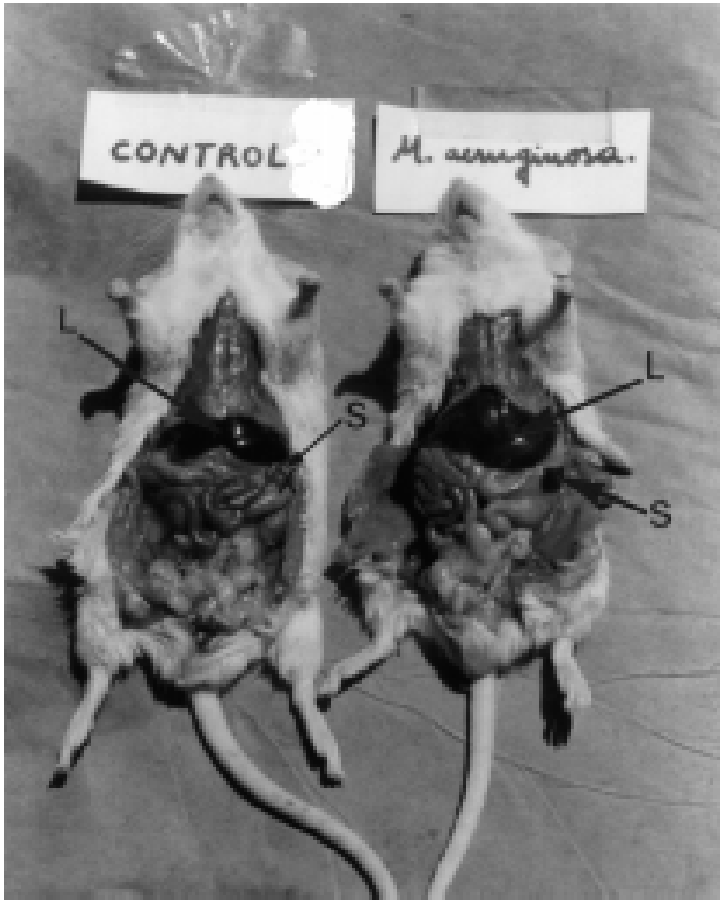

Figure 2. Photography of mice (control and inoculated with sublethal doses of $M$. aeruginosa) Showing the accentuated increase of the liver (L) and principally spleen (S) sizes in the inoculated animal.

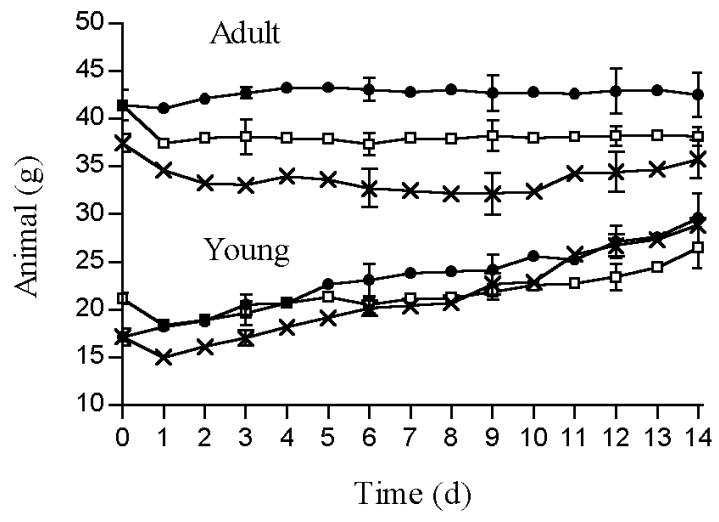

$\longrightarrow$ control $\longrightarrow$ Single dose $\longrightarrow$ Multi doses

Figure 3. Variation of weight in young and adult mice (30 and 90 days old, respectively) inoculated with $M$. aeruginosa and the control group.

adult animals, while in animals inoculated with a single dose the proportion was of $6.0 \%$ and $7.2 \%$ and in animals with multi doses, $7.0 \%$ and $7.5 \%$, in young and adult animals, respectively (Fig. 5).

According to Fig. 6, the accentuated increase in the volume (Figs. 1 and 2) and weight of the spleen
(Fig. 6) indicates the high degree of toxicity of $M$. aeruginosa. The young animals inoculated with a single dose and multi doses had an increase of $150 \%$ and $407 \%$ in the spleen while the adult animals had an increase of $607 \%$ and $845 \%$, respectively, in relation to the control. The relation between spleen weight and body weight in the control animals was around $0.12 \%$ and $0.15 \%$, respectively, for young animals and adult animals. For the animals inoculated with a single dose this relation was $0.67 \%$ and $0.37 \%$ and for those with multi doses the relation was $1.22 \%$ and $1.05 \%$, for adult and young animals, respectively (Fig. 7).

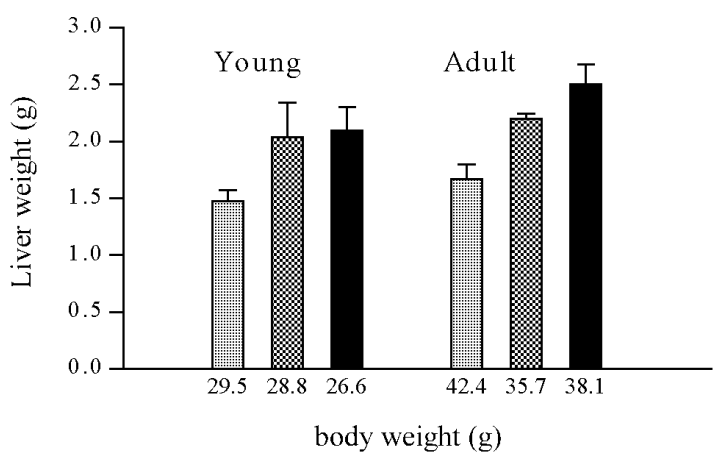

Figure 4. Hepatomegaly in young and adult mice (30 and 90 days old, respectively) inoculated with sublethal doses of $M$. aeruginosa and the control group. The horizontal numbers represent the average weight in the last day of the bioassay.

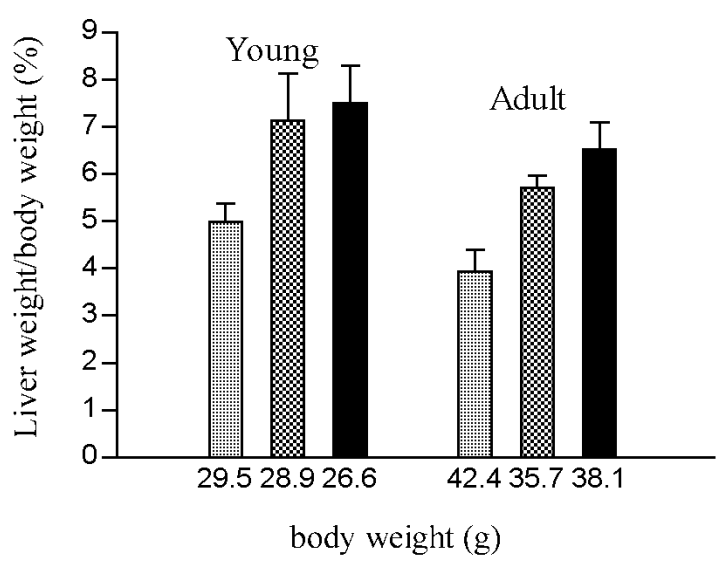

Control

Multi doses

Figure 5. Proportion between liver weight and body weight of young and adult animals (respectively, 30 and 90 days old), inoculated with sublethal doses of M. aeruginosa and the control group. The numbers represent the average weight in the last day of the bioassay. 


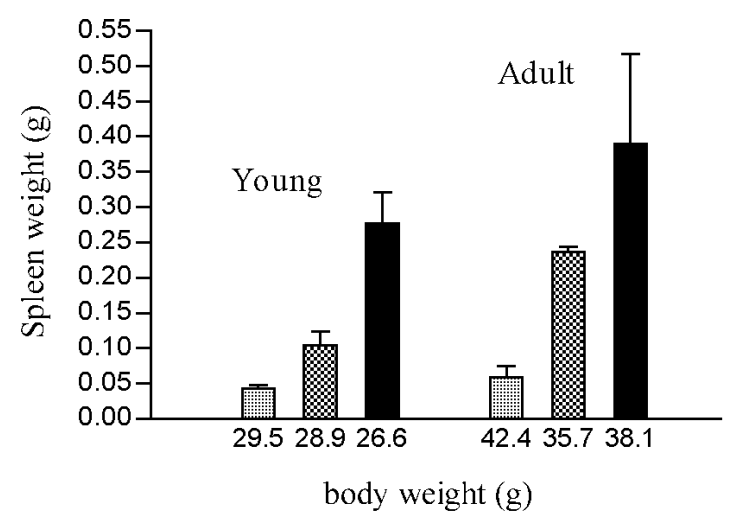

Control

Multi doses

Figure 6. Splenomegaly in young and adult mice ( 30 and 90 days old, respectively) inoculated with sublethal doses of $M$. aeruginosa and the control group. The numbers represent the average of the weight in the last day of the bioassay.

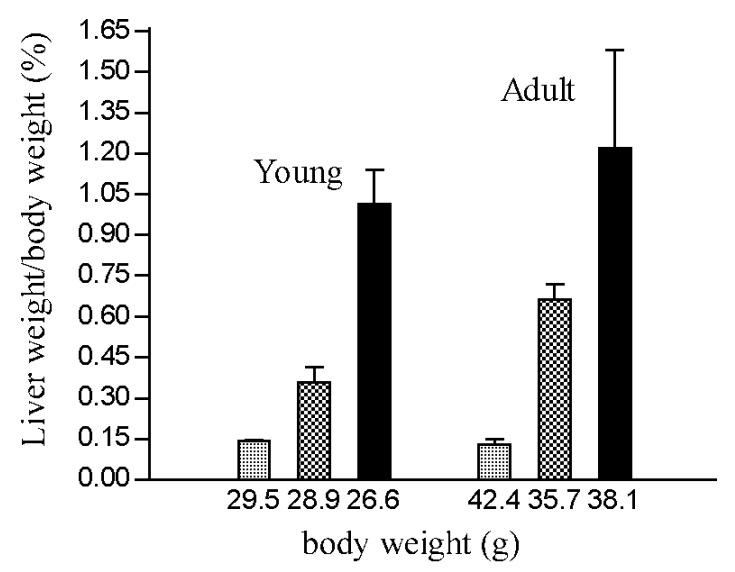

Control \%क Single dose

Multi doses

Figure 7. Proportion between spleen weight and body weight of young and adult animals (30 and 90 days, respectively old) inoculated with sublethal doses of M. aeruginosa and the control group. The numbers represent the average of the weight in the last day of the bioassay.

The histological cuts of the livers of the control animals and of those exposed to M. aeruginosa (Figs. 8 and 9) showed an outstanding difference in the structure of the hepatic parenchyma. In the intoxicated animals, a congestive and hemorrhagic aspect predominated and the light of the vases, including the sinusoid, was full of bloody globules. Another well evident aspect was a vesiculation in the cytoplasm of the hepatocyte. For this reason, the inoculated animals developed an accentuated hepatomegaly.
The Figs. 10 and 11 show a considerable increase in the number of giant multinuclear cells in the spleens of the animals inoculated with $M$. aeruginosa.

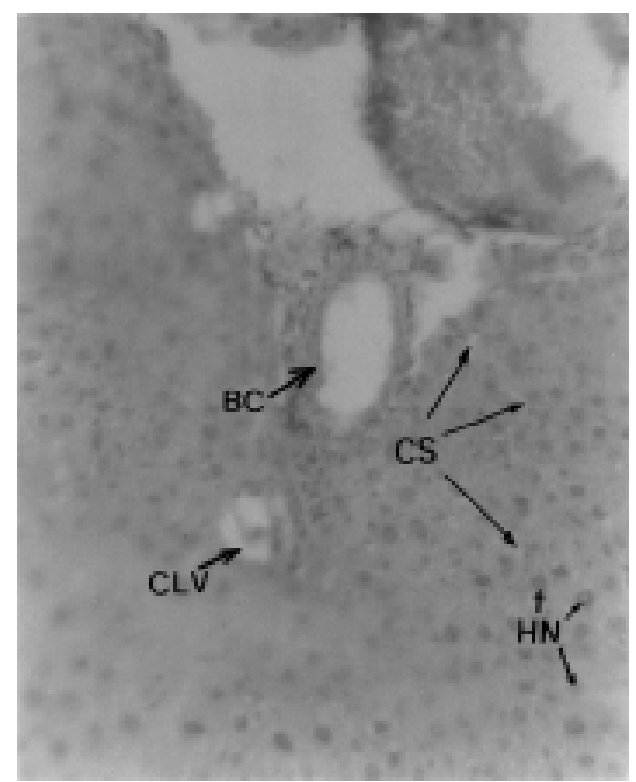

Figure 8. Microphotograph of the liver (H.E. 10X) of a control Swiss albino mice. The arrows show the biliary canaliculi (BC), the central lobular vein (CLV), the hepatocyte nucleus (HN) and the capillary sinusoid (CS).

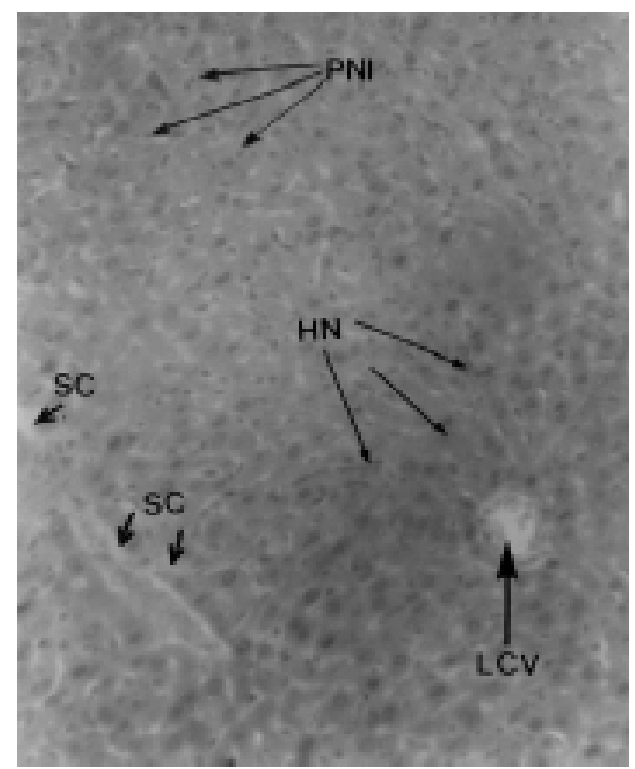

Figure 9. Microphotograph of the liver (H.E. 10X) of a Swiss albino mice inoculated with sublethal doses de $M$. aeruginosa. The arrows show capillary sinusoid (SC), lobular central vein (LCV), hepatocyte nucleus (HN) and polymorphus nuclear infiltrates (PNI). 


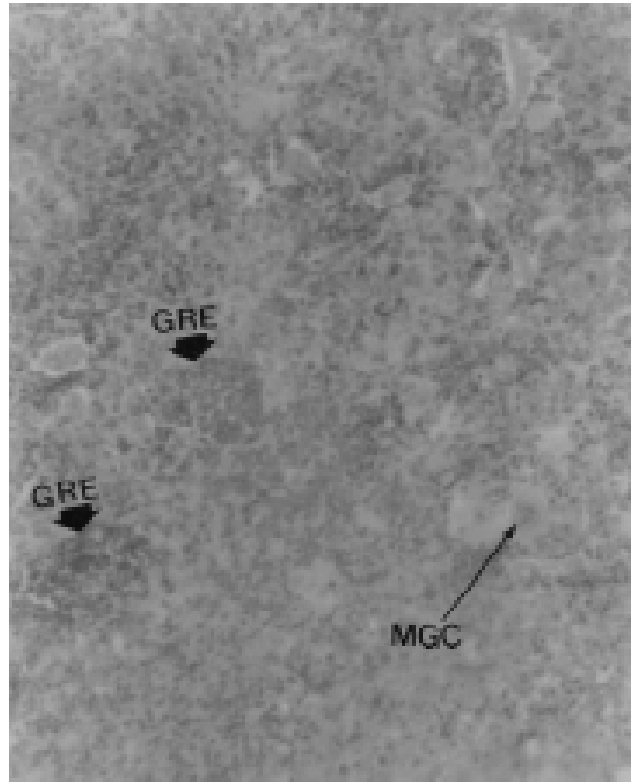

Figure 10. Microphotograph of the spllen (H.E. 10X) of a control Swiss albino mice. The arrows show groups of endothelial reticule (GRE) and some multinuclear giant cells (MGC).

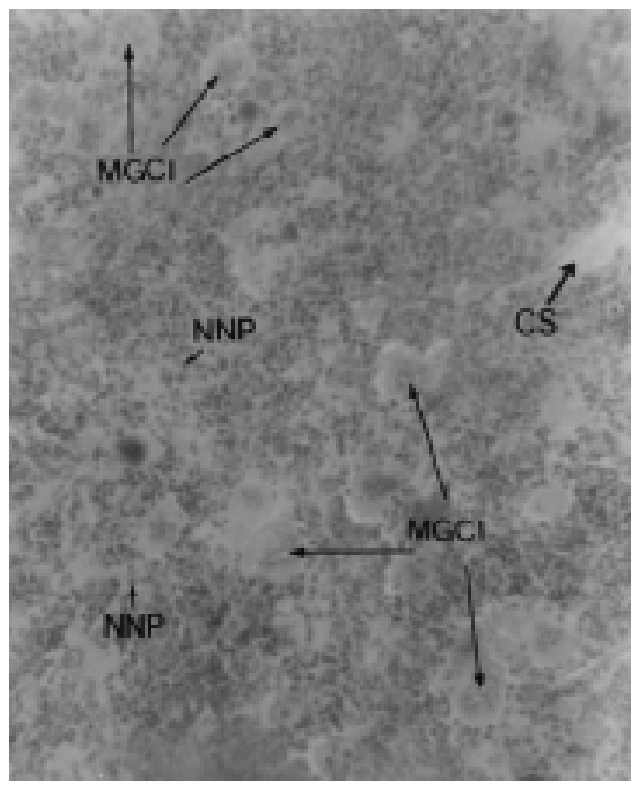

Figure 11. Microphotograph of a spleen (H.E. 10X) of a Swiss albino mice inoculated with sublethal doses of $M$. aeruginosa. The cut shows reactive alterations and the desegregation of the splenic parenchyme, with numerous nuclear polymorphus (NNP), congest sinusoid (CS) and multinuclear giant cell infiltrates (MGCI).

\section{DISCUSSION}

The microcystin-LR produced by the cyanobacterium is the best characterized toxin in the study of the hepatic toxicity in laboratory animals $(4,6)$. The hepatotoxins (mainly microcystins and nodularine) are, respectively, heptapeptides and pentapeptides that produce necrosis in the liver and are responsible for the majority of intoxication cases (4). The $\mathrm{DL}_{50}$ value found in this study (154.28mg. Kg $\left.{ }^{-1}\right)$ indicates that the material collected in the CELMM presents a high toxicity compared to other samples of cyanobacterium species collected in other localities $(19,21,26,27)$. The symptoms observed in the animals after injection of the extracts were: diarrhea, convulsions, muscle weakness, tachycardia, fluffing, etc. These symptoms are compatible with the effects described for the microcystin-LR toxin (4).

The liver is one of the most important sites of lesions caused by toxic substances due to its intense participation in the reactions of biotransformation of chemical substances of the organism. Frequently, it is affected by infectious processes and intoxications, leading to hepatomegaly (6). It's known that splenomegaly occurs as a consequence of hepatic insufficiency, which causes blood congestion in the hepatic vessel due to decrease in activity and increase in the hydrostatic pressure in this vessel. This increase causes a blood reflow through the splenic vein toward the spleen, causing its swelling. This is also attributed to the intense production of lymphaticus and to the retention of particles in the blood.

The mice bioassays is showed an increase in the weight and volume of the liver and spleen in relation to the body weight of the intoxicated animals, mainly in animals with the cumulative dose of 154.28 mg. $\mathrm{Kg}^{-1}$ (Figs. 2, 4 and 6). The pathological examination of the liver (Figs. 8 and 9) showed an intrahepatic haemorrhage which increased the volume of blood in the organ and caused hepatomegaly, a fact also verified by Salomon (21). The pathological examination of the spleen (Figs. 10 and 11) showed an increase in the giant multinuclear cells, generating an accentuated splenomegaly.

Another important fact is that when the animal undergoes successive treatments, the liver increases its volume in an attempt to recover its homeostasy 
causing the increase in volume and weight observed in the experiments. However, the exposure to the drug for a longer time provokes the fibrosis of the liver causing the decrease in the volume and weight of the organ. For this reason, the liver weight/body weight ratio was increased in the test animals, with $6.0 \%$ and $7.0 \%$ (adults) and $7.2 \%$ and $7.5 \%$ (young), respectively, inoculated with a single dose and multi doses, while the ration for the control animals was of $4 \%$ and $5 \%$, respectively for adult and young animals. It is necessary to remember that young animals present larger livers (occupying a great part of the left hypochondrium) than adult animals and consequently they were more resistant to the $M$. aeruginosa toxins. Adult and young animals were, however, highly affected by the drugs, mainly the animals inoculated with multi-doses. The toxins act in the liver causing an imbalance in the maintenance of the cell cytoskeleton, by the inhibition of the phosphatase proteins that are responsible for the production of the microfilaments responsible for the form and the holding of the cell. The most aggravating and important episode caused by $M$. aeruginosa was, however, demonstrated in the spleen (Figs. 6 and 7), where the organ weight/body weight ratios were $1.22 \%$ and $0.67 \%$ (adults) and $1.05 \%$ and $0.37 \%$ (young) for animals inoculated, respectively, with multi-doses and single dose. The control groups presented ratios of $0.12 \%$ and $0.15 \%$, respectively, for adult and young animals. The increase in the relation of the liver and spleen are justified by the decrease in the animal weight in the last day of the experiment (Fig. 3) and by the increase in the volume and the weight of the organs. In the studies with multi-doses, there was an increase of $16.6 \%$ and $72 \%$ (liver), $407 \%$ and $845 \%$ (spleen) and with a single dosage the increase was of $12 \%$ and $48.8 \%$ (liver) and $150 \%$ and $607 \%$ (spleen), respectively, in young and adult animals.

The vesiculation observed in the hepatocyte cytoplasm (Fig. 9) is also a characteristic of the microcystin effects on the cells of the liver, which have been observed as an extensive vesiculation of the granular endoplasmatic reticula (9). The $M$. aeruginosa bloom samples isolated in the estuary region of the Manguaba Lagoon presented a great hepatotoxic and splenotoxic risk for the animals that necessitate the estuary water as well as for the human population which uses such water for consumption. The chances of intoxication increases mainly when M. aeruginosa accumulates next to the margins by the action of the wind, where the contact and ingestion are much greater. The toxins in solution are hardly eliminated by the normal processes in the water treatment stations or by boiling (15). This is worrying because the experiments showed that sublethal single rate and multi-doses of the algae extract, when applied to swiss albino mice, were capable of causing hepatopathies due to the toxic action of the microcystin-LR or another type of toxin. This produces a panorama of hepatic-splenic insufficiency that leads to an increase in the volume and weight of the organs, turning impossible the biotransformation of chemical substances in the organism of the animal, causing its death.

\section{ACKNOWLEDGEMENTS}

We thank Dr. James P. Santos for his critical review of this paper. This research was partly supported by a grant from Universidade Federal de Alagoas (UFAL) and by a grant from the Conselho Nacional de Desenvolvimento Científico e Tecnológico (CNPq, Brazil).

\section{RESUMO}

\section{Hepatoesplenomegalia causada por um extrato de cianobactéria Microcystis aeruginosa coletada na Lagoa Manguaba, Alagoas -Brasil}

Cianobactérias (Microcystis aeruginosa), produtoras de potentes ciclopeptídeos hepatotóxicos conhecidos como microcistinas, foram coletadas e submetidas à determinação de toxicidade em camundongos "Swiss Albino" com 30 e 90 dias de idade, através de injeção intraperitoneal. $\mathrm{O}$ fígado e baço foram submetidos à analise histopatológica e o desenvolvimento de peso e os sinais vitais foram monitorados. $\mathrm{A} \mathrm{DL}_{50}$ no teste de toxicidade foi de $154,28 \mathrm{mg} . \mathrm{Kg}^{-1}$. Da biomassa analisada, $95 \%$ das espécies eram de Microcystis aeruginosa. A relação entre peso do fígado e peso corpóreo nos animais testes inoculados com dose única foi de $6,0 \%$ e $7,2 \%$, com multidose $7,0 \%$ e $7,5 \%$ e nos controles, foi de $4 \%$ e $5 \%$ para animais adultos e jovens, respectivamente. Houve um aumento acentuado no volume e peso do baço, em relação aos dos animais controle, onde os animais inoculados com dose única tiveram uma relação entre o peso do baço e peso corpóreo de $0,67 \%$ e $0,37 \%$, com multidose de $1,22 \%$ e $1,05 \%$ e nos controles foi de $0,12 \%$ e $0,15 \%$ para 
animais adultos e jovens, respectivamente. Os animais jovens inoculados com dose única e multidose tiveram aumento do peso e do volume do baço em $150 \%$ e $407 \%$, enquanto os adultos em $607 \%$ e $845 \%$, respectivamente, em relação ao controle. A análise histopatológica mostrou uma diferença marcante na estrutura do parênquima hepático, entre animais controles e expostos aos extratos de $M$. aeruginosa. As principais alterações observadas foram o aspecto congestivo, inclusive dos sinusóides, e hemorragia intra-hepática. Enquanto que, a análise histopatológica do baço mostrou um aumento considerado do número de células gigantes multinucleares nos baços dos animais intoxicados com a M. aeruginosa.

Palavras-chave: Microcystis aeruginosa, Cianobactéria, hepatomegalia, esplenomegalia

\section{REFERENCES}

1. Bourkr, A.T.C.; Hawes, R.B.; Neilson, A.; Stallman, N.D. An outbreak of hepato-enteritis (the Palm Island mystery disease) possibly caused by algal intoxication. Toxicon Suppl. 3: 45-48, 1983.

2. Bourrelly, P. Les Algues d'eau Douce. Initiation à la Systématique. N. Boubée Science Paris 3: 1970, 1531p.

3. Carmichael, W.W. Water Environment: Algal Toxins and Health. Environmental Science Research. vol. 20: International Conference on Toxic Algae. Plenum Press, New York, 1981.

4. Carmichael, W.W. Cyanobacteria secondary metabolites: The cyanotoxins. J. Appl. Babteriol., 72:445-459, 1992.

5. Carmichael, W.W.; Gorham, P.R. Freshwater cyanophyte toxins: Types and their effects on the use of micro algae biomass. In: Shelef \& Soeder, C.J. (ed). Algae biomass, production and use. Elsevier/North-Holland Biomedical Press. 1980, p. 437-48.

6. Carmichael, W.W. The toxins of cyanobacteria. Scient. Am. 270: 78-86, 1994.

7. Chamixaes, C.B. Produção primária do fitoplâncton relacionada com as condições ecológicas do Açude de Pipucos no Recife-Pernambuco, 1984, 240p. (Ms Thesis. Instituto Oceanográfico. UFPE.

8. Codd, G.A.; Bell, S.G.; Brooks, W.P. Cyanobacterial toxins in the water. Wat. Sci. Tech., 21 (3): 1-13, 1989.

9. Dabholkar, A.S.; Carmichael, W.W. Ultrastructural changes in the mouse liver induced by hepatotoxin from the freshwater cyanobacterium Microcystis aeruginosa strain 7820. Toxicon, 25 (3): 285-292, 1987.

10. Desikachary, T. V. Cyanophyta New Delhi. Indian Council of Agricultural Research, 1959, 686.

11. Eskinazi-Leça, E. Taxonomia e distribuição das diatomáceas Bacillariophyceae na Laguna Mundaú (Alagoas-Brasil). Recife, 1976, 100p. (Ms. Thesis Universidade Federal Rural de Pernambuco).

12. Falconer, I.R. Tumor promotion and liver injury caused by oral consumption of cyanobacteria. Environ. Toxicol. Water Qual., 6:177-184, 1991.

13. Falconer, I. R.; Burch, M. D.; Steffensen, D. A.; Choice, M.; Coverdale, O. R. Toxicity of the blue-green algal (Cyanobacterium) Microcystis aeruginosa in drinking water to growing pigs, as an animal model for human injury and risk assessment. Environ. Toxicol. and Water Qua., 9:131139, 1994.

14. Falconer, I. R.; Beresford, A. M.; Runnegar, M.T.C. Evidence of liver damage by toxin from a bloom of the blue-green alga, Microcystis aeruginosa. Med. J. Austral., 1:511-514, 1983.

15. Falconer, I. R.; Runnegar, M.T.C.; Buckley, T.; Huyhn, V. L.; Bradshaw, P. Use of powdered and granular activated carbon to remove toxicity from drinking water containing cyanobacterial blooms. J.A.W.W.A., 18:102-105, 1989.

16. Lawton, L.A.; Cood, G.A. Cyanobacterial (blue-green algal) toxins and their significance in UK and European water. $J$. IWEN. UK., 460-465, 1991.

17. Odriozola, E.; Ballabene, N.; Salamanco, A. Intoxication en ganado bovino por algas verde-azuladas. Revta. Argent. Microbiol., Buenos Aires, 4:225-236, 1984.

18. Pearson, M.J. Toxic blue- green algae. Report of the National Rivers Authority, Water Quality Series 2. UK., 1990, 127p.

19. Rao, P. 1. V.; Bhattacharya, R.; Gupta, S. D. Isolation, culture, and toxicity of the cyanobacterium (blue- green algae ) Microcystis aeruginosa from a freshwater source in India. Bull. Environ. Contam., Toxicon, 52: 878-885, 1994.

20. Rinehart, K. L.; Namikoshi, M.; Choi, B. W. Structure and biosynthesis of the toxins from blue-green algae (cyanobacteria).J. Appl. Phycol., 6: 159-176, 1994.

21. Salomon, P.S.; Yunes, J.S.; Parise, M.; Cousin, J.C.B. Toxicidade de um extrato de Microcystis aeruginosa da lagoa dos patos sobre camundongos e suas alterações sobre o tecido hepático. Vittalle, Rio Grande, 8:23-32, 1996.

22. Silva, M.G.G. Diatomáceas (Bacillariophyceae) da Plataforma Continental de Pernambuco - Brasil. Recife-PE, 1982, 348p. (Ms Thesis UFPE).

23. Sivonen, K.; Kononen, K.; Carmichael, W. W.; Dahlem, A.M.; Rinehart, K. L.; Kiviranta, J.; Niemelã, S. I. Ocorrence of the hepatotoxic Cyanobacterium Nodularia spumigera in the Baltic sea and Structure of toxin. Appl. Environ. Microbiol., 55: 1990-1995, 1990

24. Sournia, A. Le Genre Ceratium (Péridinien Planctonique) dans le canal de Mozambique; contribution a une révison mondiale. Memoire Orstom, Paris, 3:375-499, 1968.

25. Tregouboff, G.; Rose, M. Manuel de Planctonologie Méditerranéenne. Centre Nacional de La Recherche Scientifique. Tomes I-II, 587 pls. Paris. 1978, p. 207.

26. Yunes, J. S.; Salomon, P. S.; Matthiensen, A.; Beattic, H. A.; Raggett, S. L.; Codd, G. A. Toxic blooms of cyanobacteria in the Patos Lagoon Estuary, Southem Brazil. J. Aquatic Ecosystem Health, 5: 223-229, 1996.

27. Zhang, Q.Z.; Carmichael, W.W.; Yu, M.J. Cyclic peptide hepatotoxins from freshwater cyanobacterial (blue-green algae) waterblooms collected in Central China. Environ. Toxicol. Chem., 10:313-21, 1991. 